\title{
The Role of The School Committee on Infrastructure Management at Public Alementary School
}

\author{
Murni Yanto ${ }^{1)}$, \\ ${ }^{1)}$ State Islamic Institut of Curup Indonesia \\ e-mail: yantomurni65.gmail.com
}

Received: 11-10-2021

Revised: 30-11-2021

Accepted: 30-12-2021

\section{Info Artikel}

Abstract

Keywords:

Committee Role, Infrastructure Management, Primary school

Kata kunci:

Peran Komite, Manajemen Sarana Prasarana, Sekolah Dasar

\begin{abstract}
The school committee is a partner of the principal who has a role as a giver of consideration, as a supporter, as a supervisor, and as a mediator. All of these roles cannot stand alone but have a relationship between one role and another. In this study, the authors used a qualitative approach. The purpose of the article is to find out activities related to the objectives of the research. The subjects in this study were school committees, principals, teachers, and students' guardians. The results of the article are that the condition of facilities and infrastructure at the Karang Jaya 1 public elementary school is generally adequate, although there is still a shortage of supporting media such as projectors, the teaching and learning process is still not available.
\end{abstract}

\begin{abstract}
Abstrak
Komite sekolah merupakan mitra kepala sekolah yang memiliki peran sebagai pemberi pertimbangan, sebagai pendukung, sebagai pengawas dan sebagai mediator. Ke semua peran itu tidak dapat berdiri sendiri akan tetapi memiliki keterkaitan antara peran yang satu dengan peran yang lainnya. Pada penelitian ini penulis menggunakan pendekatan kualitatif. Tujuan artikel yakni mengetabui kegiatan yang berkenaan dengan tujuan dari penelitian. Subjek dalam penelitian ini yaitu komite sekolah, kepala sekolah, guru dan wali siswa. Hasil dari artikel adalah kondisi sarana dan prasarana di sekolah dasar negeri 1 Karang Jaya secara garis besar sudab cukup memadai, meskipun masih ada kekurangan media pendukung seperti proyektor belum ada namun tetap proses belajar mengajar.
\end{abstract}

\section{INTRODUCTION}

The world of education has an important role with the aim of educating the nation's life, so the people involved in it are required to work together to improve the quality of education. Related to the importance of quality improvement, the government makes efforts to realize these goals, namely by developing and innovating the curriculum, procuring teaching materials that are appropriate to the situation and conditions, and conducting training for teachers and other education personnel (Mulyasa, 2002).

The change in government which was initially centralized to decentralized created new opportunities for people, in particular, to participate in managing the world of education. Various efforts have been made in realizing opportunities for improving the world of education and participation through the education world council, school committees, all of which refer to 
laws made by the government, namely the law on the national education system which states that school/madrasab committees are independent institutions. and consists of parents/guardians of students, madrasa residents, and includes religious leaders or community leaders who have the function of a deliberative board regarding school management.

In the management of policies regarding the implementation of education which is a result of the existence of Law No. 22 of 1999 concerning regional governments and Law No. 25 of 199 regarding financial balance between central and regional governments, which are further clarified into law. 32 of 2004 concerning local government. Among the components in government administration that are transferred to the provincial or district level I and level II are the process of organizing the world of primary and secondary education, all of which include elementary, junior high to STA (Syukur, 2008).

Education is part of human effort to gain broader knowledge to shape character in the form of values, behavior, and attitudes in the world of education. Education is basically occupying a very strategic place because education will create and grow a generation that is able to be responsible for religion, nation, and state. Education is also a process of providing debriefing, guiding the growth and outward development (basic abilities) of students (Bahri \& Arafah, 2020; Pakpahan \& Habibah, 2021).

Then UUSPN No. 20 of 2003 which has article 56 paragraph (1) which explains that the community plays a role in improving the quality of providing educational services which are carried out through the education world council and school or madrasa committees consisting of planning, monitoring, and evaluation. Furthermore, paragraph (2) explains that the education world council is an independent forum that is formed and has a role to improve the quality of education services by providing considerations, suggestions, and support in terms of personnel, with regard to facilities and infrastructure as well as the implementation of supervision at the national level, provincial and district or city levels that are not hierarchically related. While the explanation regarding the formation of school committees or madrasas as independent forums is built and has a role in improving the quality of services by making considerations, suggestions, and assistance in the form of personnel, facilities, and infrastructure as well as monitoring at the education unit level.

The school committee can also directly in the form of assessment assessments for development in the implementation in the world of education, both in terms of intra-curricular activities, it can also be found in the implementation of school management which consists of the school itself, the principal as a leader, the teacher as student teaching staff as the target object. and employees who assist in the implementation of management and give appreciation for the success of school management. In addition, the school committee can also provide suggestions regarding the submission of the RAPBS.

Kepmendiknas 044/U/2002 mentions the role of the School Committee which carries out four roles, namely: (1) building, (2) supporting, (3) supervisor, and (4) mediator. The four roles are independent roles, but rather interrelated roles.

When viewed from the role of committees in schools, from the beginning the school was welcomed and positively by the community who had high hopes for the school committee. However, in reality, in the field, such as in schools, important facts were found where school committees were unclear about their existence and in the field. The reason is that the implementation carried out by the committee has not been able to realize the expectations of the community (Azizah \& Apdila, 2021; Khosyi’in, 2021; Solechan, 2021). 
As we know the existence of school committees is very important and has strategic things including (1) school committees are able to provide consideration and input in the implementation of education policies (2) support in the form of funds, thoughts and energy in the implementation of world education, (3) supervision activities to the implementation of education and (4) as a mediator or intermediary between the government and the community in the world of education units (Rohiat, 2008).

The role of committees in schools is still very varied. On other hand, the School Committee is often referred to as the "cap" of the madrasah head. This means that school committees like this only "follow" what is programmed by the head of the madrasa. Sometimes school committees lack creative ideas and innovative ideas to improve student learning outcomes. So the principal's program is a school committee program.

Sometimes the madrasah principal is often the target of criticism and excessive supervision by the school committee, especially if the madrasah principal is not transparent, democratized and accountable. If the principal clearly makes the decision, the Committee does not hesitate to submit a recommendation to the education office to determine the principal. The role as a supervisory body is more prominent than others. Even in some madrasas, the existence of this institution is a match for the principal in determining school policy (Puspito et al., 2021; Yanto, 2021).

The bond between the school committee and the principal that is carried out properly can have a good impact on the school committee in building educational resources in realizing the implementation of education management that can provide a means for educators to gain as much knowledge as possible, so that the learning process can be carried out. run effectively (Karim et al., 2021; Syukkur \& Fauzan, 2021).

The school committee can participate in supervising the learning problems faced by educators both individually and as a group, so that it can help the teacher's task to provide learning methods that are in accordance with the conditions of their students. The school committee can also provide aspirations or complaints from the guardians of students regarding low student achievement when achieved by a madrasa.

The implementation of the role of committees in schools is currently highly expected and also needs to be disclosed as it is. In fact, many educational institutions or institutions have not been able to provide satisfactory services to the user community, especially educational institutions with private status located in remote villages (Pahlawanti et al., 2020).

This condition clearly requires a role in the form of action from the school committee, both in terms of management and the smooth running of learning activities. Therefore, research on the role of the committee is interesting to see how far the implementation of the role of the school committee is and the factors that influence the implementation of that role (Hidayati et al., 2021).

Educational devices in the form of educational facilities are equipment that can be used to support the learning process in the world of education (Ma'arif \& Nabila, 2020). The facilities in a school are in the form of meeting halls, local, blackboards, tables and chairs and media or other learning tools. When discussing facilities, of course, it will be juxtaposed with infrastructure which is a supporter of the teaching and learning process. Examples of infrastructure include school yards, school gardens, school parks, access to schools is in the form of roads and can also be used directly, for example, school parks used for biology lessons. SDN 1 Karang Jaya is one 
of the educational institutions which is one of the districts that is in South Sumatra. As a formal educational institution.

Broadly speaking, the facilities and infrastructure at SDN 1 Karang Jaya are adequate, this can be seen from the proper class conditions for the teaching and learning process, media such as the projector, the presence of which helps teachers and students to access activities related to learning.

\section{METHOD}

Methodology with a qualitative approach is a research procedure that produces descriptive data in the form of written or spoken words from people and observable behavior. Qualitative research is research that describes or explains about a social phenomenon. Researchers have a strong relationship with data sources, because researchers go directly to the field and integrate with them as sources of information (Moleong, 1989). In essence, qualitative research is observing people in their environment, interacting with them deeply and continuously so that the relationship between the researcher and the object of research is very close and has a fairly high intensity of interaction (Creswell, 2012).

\section{RESULT AND DISCUSSION \\ School Committee}

In school-based management, school committees and principals have a role as partners to work together in improving the quality of education. For this reason, it is hoped that there will be no disputes between them. Cooperation between the madrasa and the community in this case is represented by the school committee to empower abilities in the education unit and the capabilities possessed by the community as stated in Article 4 paragraph 6 of the UUSPN Number 20 of 2003 which explains about "education is carried out by empowering every component of society through participation in the implementation and quality control in services in the world of education."

The School/Madrasah Committee is an independent institution consisting of parents/guardians of students, the school community, and community leaders who care about education. The School Committee is an independent body that accommodates the participation of the community in the context of improving the quality, equity and efficiency of education management in education units, both in preschool education, school education pathways.

The School Committee consists of two words, each of which has its own meaning. Pius A Partanto (1994) (Rais, 2012) says that "committees are bodies, councils, commissions, committees". While in the Big Indonesian Dictionary it is said that"committees are a number of people appointed to carry out certain tasks (especially in relation to the government).

The School Committee is an independent body that accommodates community participation in order to improve equity and efficiency in the management of education in madrasas, which acts as a board that provides considerations, supports, controls, and mediators in the implementation and management of education in madrasa.

Meanwhile, in Educational Autonomy, (Hasbullah, 2006) said that the school committee is an agency that oversees the participation of the community in improving the quality, equity and savings in education management in educational units, both in terms of premadrasa education, madrasa education routes and outside school. 
From the various opinions above, the researcher can conclude that the School Committee is an independent body as a partner, principal and government in improving the quality, equity, and efficiency of education management.

\section{Role of School Committee}

Roles are dynamic aspects of a status. A person who carries out the rights and obligations means that he has carried out a role. The role refers to a function, adjustment and as a process. The role of parents and society in education is important for the following reasons: 1) So far, the role of parents and the community has been given more to private schools/madrasah, it has succeeded in boosting the quality of education as we know that many private educational institutions are experiencing rapid progress, 2) The involvement of the role of parents and the community in the implementation of education will be more effective with the synergy between the central government and local governments (Mulyasa, 2003).

The implementation of the roles and functions of the School/Madrasah Committee is largely determined by the process of its formation. The process of forming a School Committee must adhere to three modern management principles, namely: 1) democratic, 2) transparent and 3) accountable. If the process of forming the School Committee does not adhere to these three principles, it is certain that the School Committee can never carry out its roles and functions optimally, even as long as it is formed and ironically the School Committee only follows what the Principal wants (As long as you are happy), so it is not in accordance with what is expected by society.

\section{Facilities and Infrastructure Management}

Understanding the management of facilities and infrastructure in the world of education is defined as the implementation of cooperation, the use of all facilities and infrastructure that is carried out efficiently and effectively. This understanding proves that the use of facilities and infrastructure must be carried out and used for the learning process in the madrasa. This is so that the use of existing facilities and infrastructure in a madrasa can run well.

Management is a series of activities designed to achieve organizational goals by using resources efficiently and effectively and carried out in an environment that always forms from time to time effectively achieving goals by using as few available resources as possible.

Management comes from the word To Manage which means to manage. Arrangements are made through processes and are arranged according to the order and functions of the management. G.R. Terry states that management is a distinctive process consisting of planning, organizing, directing and controlling actions carried out to determine and achieve predetermined goals through the use of human resources and other resources. So, management is a process to realize the desired goals there is a close relationship between organization, administration and management (Prastyawan, 2016).

Management or management is an inseparable component of the education process as a whole, without management, the goals of education cannot be realized optimally, effectively, and efficiently. All educational institutions or institutions require effective and efficient management. The purpose of effective and efficient here is to be effective and efficient. This means that successful management achieves goals by saving energy, time, and costs (Muslimin \& Kartiko, 2020).

The existence of facilities and infrastructure that supports the educational process does not run as it should. Mulyasa, in MBS stated that "educational facilities are equipment and supplies that are directly used to support the educational process, especially the teaching and 
learning process, such as buildings, classrooms, tables, chairs, and teaching tools and media. Educational infrastructure is facilities that indirectly support the course of the education or teaching process, such as yards, gardens, parks, roads leading to learning, but if used directly for the teaching and learning process, such as parks used for teaching biology, courtyards as sports fields. these components are educational facilities."

Management of facilities and infrastructure is a series of very important processes in a school, where its existence plays a very important role in the success or failure of the learning process in madrasas. The purpose of facilities relating to the world of education is equipment that is used directly and can support the learning process. Examples of facilities related to the world of education are classrooms, desks, chairs, school buildings, teaching tools and media according to Suharto. According to the Ministry of National Education, infrastructure is a facility that includes supporting the teaching and learning process (Indrawan, 2015).

Ary H. (Gunawan, 1996) said that "administrative activities for educational facilities and infrastructure include planning, pre-qualification, procurement, storage, maintenance, removal and control" Ibrahim (Bafadal, 2003)stated that "educational facilities are all equipment, materials, and parabots that are directly used in the education process in madrasas" While educational infrastructure is all basic equipment that indirectly supports the implementation of the educational process in schools.

(Mulyasa, 2002)said that:

"Educational facilities are equipment and supplies that can be used directly and support the educational process, especially the teaching and learning process such as: buildings, classrooms, desks and chairs, as well as learning media tools. While what is meant by educational infrastructure in the learning process, such as: madrasa yard, madrasa garden, madrasa park, and the road to school."

\section{Syahril in (Khoiriyah et al., 2016) also said that}

"Facilities are elements that can be used directly in the implementation of an activity, as well as support in the implementation of the teaching and learning process. These elements can take the form of: tables, chairs, chalk, blackboards, props and so on."

From some of the definitions above, it can be concluded that educational facilities are all facilities that can support the educational process directly, while educational infrastructure is a facility that indirectly supports the educational process. So, the management of educational facilities and infrastructure can be interpreted as a comprehensive activity that starts from the planning, procurement, use, maintenance and elimination process in an educational institution.

Ary H. Gunawan explained that management of educational facilities is the whole process of activities that are planned and endeavored intentionally and seriously as well as gradual development of educational objects, so that they are always ready for us in the teaching and learning process so that PBM is more effective. and efficient to help achieve the educational goals that have been set. Meanwhile, according to Rohiat, management of facilities and infrastructure is an activity that regulates to prepare all equipment or materials for the implementation of the educational process in schools. Management of facilities and infrastructure is needed to help smooth the teaching and learning process." 
The quality of education is a unit that is interconnected and related to the process of implementing a system. Talking about the quality of education, it cannot be separated from the three elements of education, namely input, process and graduates.

Based on the description above, it can be concluded that the management of educational facilities and infrastructure is tasked with regulating educational facilities and infrastructure so that they can contribute optimally and meaningfully to the course of the educational process.

\section{Management of Facilities and Infrastructure in Schools}

Good facilities and infrastructure require good management of facilities and infrastructure as well. This aims to control the need for the necessary facilities and infrastructure as well as the organized state of the facilities and infrastructure in the school. Facilities and infrastructure management is an effort to manage existing facilities and infrastructure in schools, in order to support the smooth running of all teaching and learning activities or other activities carried out in schools (Bancin \& Lubis, 2017).

Management of educational facilities and infrastructure is all arrangements for facilities and infrastructure owned by educational institutions. Arrangements are made by going through a process and arranged based on the sequence and management functions. By applying the principles of management, advice and educational infrastructure starting from the planning, procurement, inventory, storage, distribution, maintenance, deletion and assessment and supervision processes, schools will be able to fulfill educational facilities and infrastructure in a well-planned and planned manner (Kawasaki et al., 2017).

Lestari et al stated that infrastructure management is an effort to plan, procure, distribute, maintain, maintain, and inventory the facilities and infrastructure in each school. Other studies also say that the management of facilities and infrastructure is a planned management in managing facilities and infrastructure in schools (Arnold et al., 2019).

The purpose of facilities and infrastructure management is to realize the planning and procurement process for the necessary infrastructure, optimal use of facilities and infrastructure, especially the care and maintenance of existing facilities and infrastructure in schools. The implementation of good and organized management of facilities and infrastructure has a direct impact on the optimal learning process carried out in schools and the resulting output.

This statement agrees with Prastyawan's opinion, which explains that good infrastructure management will obtain outputs or results with educational ideals so that students are able to adapt and contribute to social life. In addition, the purpose of the management of facilities and infrastructure is to increase the effectiveness of optimal teaching and learning activities so that improvements can be made to the quality of education even better. If the infrastructure is well maintained, it will minimize the risk of student learning failure. Meanwhile, in infrastructure maintenance management activities, one of them is an analysis of the needs of both students and teachers. This needs analysis is the goal of infrastructure management itself in teaching and learning activities (Prastyawan, 2016).

\section{Facilities and Infrastructure Management Process}

The processes carried out in the management of facilities and infrastructure include planning, procurement, regulation, use, and elimination. The five processes when combined will form a facility and infrastructure management cycle as follows: 


\section{Planning}

Planning comes from the word plan which means the design or framework of something that will be done in the future. The process of designing efforts to purchase, rent, exchange, borrow, recycle, recondition/rehabilitate, distribute or manufacture equipment and supplies that are in accordance with school needs, is the planning of educational facilities and infrastructure.

The initial process of facilities and infrastructure management is planning. This planning process is carried out to find out what facilities and infrastructure are needed. The principal, deputy head, teacher council, head of administration, treasurer, and madrasah committee as the school supervisory body are the elements involved in this process.

This planning function is an important factor needed to achieve the goal. To carry out activities that are consistent with the various objectives and selected procedures and progress can be continuously monitored and measured, so that corrective action can be taken if the level of progress is not satisfactory, a planning function is required.

\section{Procurement}

The provision of various types of facilities and infrastructure that are needed based on the educational design if in management it is called procurement. The need for facilities and infrastructure can be in the form of specific types, quantities, times, locations and prices including where they come from which can be accounted for. The procurement of facilities and infrastructure is carried out after the planning stage. In essence, this function is a series of activities to provide educational facilities and infrastructure in madrasas in accordance with previously planned needs.

\section{Settings}

If the procurement has been carried out, then the next process is the arrangement of facilities and infrastructure where the arrangement of facilities and infrastructure here consists of activities, namely inventory or recording, storage and maintenance or guarding.

Taking notes or taking an inventory is an activity carried out to arrange the existing facilities and infrastructure in an orderly, orderly and complete manner based on the applicable provisions, called an inventory. Facilities and infrastructure originating from the government (owned by the state) must be inventoried. With this inventory, we will easily find out the quantity, type of goods, quality, year of manufacture, brand/size, and price of goods in the madrasa.

Storage: The activity of storing educational facilities and infrastructure in a place so that the quality and quantity of goods is guaranteed is a storage activity. Storage activities include: receiving goods, storing goods, and issuing goods. Then the items are stored in a room.

Maintenance: Maintenance of facilities and infrastructure is intended to be a process of setting so that facilities and infrastructure are always in good condition and ready to be used efficiently to lead to expectations in the world of education.

Usage: Utilization is an activity of utilizing educational facilities and infrastructure to support the educational process in order to achieve educational goals. The process of use is the use of educational facilities and infrastructure to support the educational process. There are two principles that must be considered in the use of educational equipment, namely the principle of effectiveness and the principle of efficiency. The principle of effectiveness means that all use of educational equipment in madrasas should be aimed solely at facilitating the achievement of school educational goals. The principle of efficiency means that all educational equipment is used sparingly and carefully so that all existing equipment is not easily depleted, damaged and lost. 
Removal: Elimination of facilities and infrastructure is the activity of removing/removing facilities and infrastructure from the inventory list because facilities and infrastructure are considered not functioning as expected, especially for the benefit of implementing learning in schools.

\section{CONCLUSION}

The condition of the facilities and infrastructure at the State Elementary School 1 Karang Jaya is generally adequate, this can be seen from the neat arrangement of the classroom and teacher's room, the existence of supporting media such as praga tools that can be used in the learning process, the state of the clean school environment. and beautiful. In addition, the existing facilities and infrastructure at SDN 1 Karang Jaya have increased, this is indicated by the addition of classroom buildings. Management of facilities and infrastructure at State Elementary School 1 has been going well, this can be seen from the planning where the school committee always coordinates with the school in every activity such as how to obtain funds for class construction, adding tables and chairs, this can It can be seen that there is good cooperation between the school committee and the school. Borrowing books in the library is often late so that students are subject to sanctions, from students who eliminate library books, they are obliged to replace them. Inventory in schools has been carried out by assigning a numbering code to the facilities obtained from government assistance. At the maintenance stage, the facilities are stored in a place that has been provided so that the equipment is not easily damaged. can no longer be used, with the aim of facilitating administration, after the deletion process is then made an official report on the removal and removal of the goods. In this setting stage the inventory, maintenance and storage committee acts as a controller, also at the stage of use and elimination.

The role of the school committee has been running well in the management of facilities and infrastructure from the planning, procurement, regulation, use and disposal stages at SDN 1 Karang Jaya. This can be seen at the planning stage, the role of the committee as a giver of consideration in the preparation of the RAPBS, holding fundraising in committee meetings with the guardians of students and seeking funds for the procurement of infrastructure here, the role of the committee as a supporting body. As a supporting body, the school committee of course always supports every design in the school as long as it is related to the progress of the school and as a mediator the committee becomes a liaison in the community in the form of suggestions, proposals and improvements. Inhibitors: there are several school committee members who work less than optimally, the active performance of committee members is only limited to certain people. This is often complained by the committee chairman to the school because it makes the performance of the school committee at this school a bit hampered.. 


\section{REFERENCES}

Arnold, U., Söbke, H., \& Reichelt, M. (2019). SimCity in Infrastructure Management Education. Education Sciences, 9(3), 209. https://doi.org/10.3390/educsci9030209

Azizah, M., \& Apdila, M. N. (2021). Peran Kepala Madrasah Sebagai Supervisor dalam Peningkatan Kinerja Guru. Chalim Journal of Teaching and Learning (CJoTL), 1(1), 73-84.

Bafadal, I. (2003). Peningkatan profesionalisme guru sekolah dasar dalam kerangka manajemen peningkatan mutu berbasis sekolah. Bumi Aksara.

Bahri, S., \& Arafah, N. (2020). Analisis Manajemen SDM Dalam Mengembangkan Strategi Pembelajaran Di Era New Normal. Tafkir: Interdisciplinary Journal of Islamic Education, 1(1), 20-40. https://doi.org/10.31538/tijie.v1i1.2

Bancin, A., \& Lubis, W. (2017). Manajemen Sarana Dan Prasarana Pendidikan (studi Kasus Sma Negeri 2 Lupuk Pakam). EducanduM, 10(1), 62-69.

Creswell, J. W. (2012). Qualitative Inquiry and Research Design: Choosing Among Five Approaches. SAGE Publications.

Gunawan, A. H. (1996). Administrasi sekolah: (Administrasi pendidikan mikro). Penerbit Rineka Cipta.

Hasbullah. (2006). Otonomi pendidikan: Kebijakan otonomi daerah dan implikasinya terhadap penyelenggaraan pendidikan. RajaGrafindo Persada.

Hidayati, R. F., Arafat, Y., \& Putra, A. Y. (2021). The influence of the leadership of the principal and school committee on teacher performance. JPGI (Jurnal Penelitian Guru Indonesia), 6(2), 465-471. https://doi.org/10.29210/021072jpgi0005

Indrawan, I. (2015). Pengantar Manajemen Sarana dan Prasarana Sekolah. Deepublish.

Karim, A., Kartiko, A., Daulay, D. E., \& Kumalasari, I. D. (2021). The Effect of The Supervision of The Principal and The Professional Competency of Teachers on Teacher Performance in Private MI in Pacet District. Nidhomul Haq: Jurnal Manajemen Pendidikan Islam, 6(3), 497-512. https://doi.org/10.31538/ndh.v6i3.1686

Kawasaki, A., Ichihara, N., Ochii, Y., Acierto, R. A., Kodaka, A., \& Zin, W. W. (2017). Disaster response and river infrastructure management during the 2015 Myanmar floods: A case in the Bago River Basin. International Journal of Disaster Risk Reduction, 24, 151-159. https://doi.org/10.1016/j.ijdrr.2017.06.004

Khoiriyah, S., Sudjarwo, S., \& Rini, R. (2016). Manajemen Sarana Prasarana Pendidikan Sdn 1 Pendowo Asri Dente Teladas Tulang Bawang. JURNAL MANAJEMEN MUTU PENDIDIKAN, 4(3), Article 3. http://jurnal.fkip.unila.ac.id/index.php/JMMP/article/view/11798

Khosyi'in, A. (2021). Peran Kepemimpinan Kepala Sekolah, Pengambilan Keputusan, Dan Budaya Organisasi Terhadap Disiplin Kerja. Chalim Journal of Teaching and Learning (CJoTL), 1(1), 45-55.

Ma'arif, M. A., \& Nabila, N. S. (2020). The Contribution Of Kiai Munawwar Adnan Kholil Gresik On Islamic Education. Tribakti: Jurnal Pemikiran Keislaman, 31(2), 218-236. https://doi.org/10.33367/tribakti.v31i2.1126

Moleong, L. J. (1989). Metodologi penelitian kualitatif. Remadja Karya.

Mulyasa, E. (2002). Manajemen berbasis sekolab: Konsep, strategi, dan implementasi. Remaja Rosdakarya.

Mulyasa, E. (2003). Menjadi kepala sekolah profesional: Dalam konteks menyukseskan MBS dan KBK. Remaja Rosdakarya. 
Muslimin, T. A., \& Kartiko, A. (2020). Pengaruh Sarana dan Prasarana Terhadap Mutu Pendidikan di Madrasah Bertaraf Internasional Nurul Ummah Pacet Mojokerto. Munaddhomah: Jurnal Manajemen Pendidikan Islam, 1(2), 75-87. https://doi.org/10.31538/munaddhomah.v1i2.30

Pahlawanti, W. D., Harapan, E., \& Wardiah, D. (2020). The Influence of School Principal Supervision and School Committee Participation on the Quality of Junior High School Education. International Journal of Progressive Sciences and Technologies, 23(1), 324-333. https://doi.org/10.52155/ijpsat.v23.1.2260

Pakpahan, P. L., \& Habibah, U. (2021). Manajemen Program Pengembangan Kurikulum PAI dan Budi Pekerti dalam Pembentukan Karakter Religius Siswa: Management of IRE Curriculum Development Program and Character in Forming Student's Religious Character. Tafkir: Interdisciplinary Journal of Islamic Education, 2(1), 1-20. https://doi.org/10.31538/tijie.v2i1.19

Prastyawan, P. (2016). Manajemen Sarana Dan Prasarana Pendidikan. Al Hikmah: Jurnal Studi Keislaman, 6(1), Article 1. https://doi.org/10.36835/hjsk.v6i1.2797

Puspito, G. W., Swandari, T., \& Rokhman, M. (2021). Manajemen Strategi Pengembangan Pendidikan Non Formal. Chalim Journal of Teaching and Learning (CJoTL), 1(1), 85-98.

Rais, H. E. (2012). Kamus ilmiah populer: Memuat berbagai kata dan istilah dalam bidang politik, sosial, budaya, sains dan teknologi, psikologi, kedokteran, pendidikan. Pustaka Pelajar.

Rohiat. (2008). Manajemen sekolah: Teori dasar dan praktik. Refika Aditama.

Solechan, S. (2021). Implementasi Sistem Informasi Manajemen Di Smp Islam Terpadu Al Ummah Jombang: Implementation of Management Information Systems at Al Ummah Integrated Islamic Junior High School Jombang. Chalim Journal of Teaching and Learning (CJoTL), 1(1), 8-19.

Syukkur, A., \& Fauzan, F. (2021). Improving The Quality of Education Through The Principal's Strategy to Develop Teacher Competence. Nazhruna: Jurnal Pendidikan Islam, 4(3), 563574. https://doi.org/10.31538/nzh.v3i1.402

Syukur, F. (2008). Manajemen madrasah berbasis pesantren: Studi di madrasah Raudlatul Ulum Guyangan Pati. IAIN Walisongo.

Yanto, M. (2021). Management Problems of Madrasah Diniah Takmiliyah Awaliyah Rejang Lebong Old Religious Units in Memorizing Al-Qur'an Juz Amma. Nazhruna: Jurnal Pendidikan Islam, 4(2), 235-248. https://doi.org/10.31538/nzh.v4i2.1433 